\title{
POPULATION STRUCTURE AND PRODUCTION OF COPAIBA OLEORESIN BETWEEN VALLEYS AND HILLSIDES OF THE MINING AREA OFTROMBETAS RIVER - PARÁ ${ }^{1}$
}

Jonas Gebara ${ }^{2 *}$, Antenor Pereira Barbosa ${ }^{3}$, Isabel Maria Gonçalves Azevedo ${ }^{4}$ e Bruno Oliva Gimenez ${ }^{2}$

\footnotetext{
${ }^{1}$ Recebido em 10.07.2014 aceito para publicação em 01.12.2015.

${ }^{2}$ Instituto Nacional de Pesquisas da Amazônia, Programa de Pós Graduação em Ciências de Florestas Tropicais, Manaus, AM - Brasil. E-mail: <jonas@kirwane.org.br>e < bruno.oliva.gimenez@gmail.com>.

${ }^{3}$ Instituto Nacional de Pesquisas da Amazônia, Coordenação de Pesquisas em Silvicultura Tropical, Manaus, AM - Brasil. E-mail: <antenor@inpa.gov.br>.

${ }^{4}$ Universidade Federal do Amazonas, Manaus, AM - Brasil. E-mail: <isa_florestal@yahoo.com.br>.

*Autor para correspondência.
}

\begin{abstract}
We aimed in this work to study natural populations of copaiba (Copaifera multijuga Hayne) on the Monte Branco mountain at Porto Trombetas-PA, in order to support sustainable management and the exploitation of oleoresin from copaiba. We studied the population structure of copaiba on hillsides and valleys of the south face of Monte Branco, within Saracá Taquera National Forest, where bauxite ore was extracted in the biennium 2013-2014 by Mineração Rio do Norte (MRN). We produced a 100\% forest inventory of the specie and of oleoresin extraction in order to quantify the potential production of the remaining area. The density of copaiba individuals with $\mathrm{DBH} \geq 30 \mathrm{~cm}$ was 0.33 individuals per hectare in the hillside and 0.25 individuals per hectare in the valley. Both environments presented a density of 0.28 individuals per hectare. The average copaiba oleoresin yield was $0.661 \pm 0.334$ liters in the hillside and $0.765 \pm 0.280$ liters in the valley. The average value of both environments together (hillside and valley) was $0.714 \pm 0.218$ liters. From all individuals with DBH over $30 \mathrm{~cm}, 38(58 \%)$ produced some amount of oleoresin, averaging $1.113 \pm 0.562$ liters in the hillside, $1.329 \pm 0.448$ liters in the valley and $1.190 \pm 0.355$ liters in both environments together. The results show the need for planning the use of the surroundings of the study area in order to reach the required volume of copaiba to make feasible the sustainable management of oleoresin extraction in the region.
\end{abstract}

Keywords: Biometrics; Copaiba Oleoresin; Natural population.

\section{ESTRUTURA POPULACIONAL E PRODUÇÃO DE ÓLEO-RESINA DE COPAÍBA ENTRE VALES E ENCOSTAS DE ÁREA DE MINERAÇÃO NO RIO TROMBETAS-PARÁ}

\begin{abstract}
RESUMO - O objetivo deste trabalho foi estudar as populações naturais de copaíba (Copaifera multijuga Hayne) na serra Monte Branco, em Porto Trombetas-PA, para subsidiar o manejo sustentável e a exploração de óleo-resina da espécie. Foi estudada a estrutura populacional da copaíba nas encostas e vales remanescentes da face Sul da serra Monte Branco, dentro da Floresta Nacional Saracá-Taquera, onde fora extraído o minério bauxita das áreas de platô no biênio de 2013-2014 pela Mineração Rio do Norte (MRN). Foi feito o inventário florestal a 100\% da espécie e a extração do óleo-resina para quantificar o potencial produtivo das áreas remanescentes. A densidade de indivíduos de copaíba com $D A P \geq 30 \mathrm{~cm}$, na encosta, foi de 0,33 indivíduo por hectare, no vale foi de 0,25 indivíduo por hectare, e nos dois ambientes a densidade foi de 0,28 indivíduo por hectare. A média de produtividade

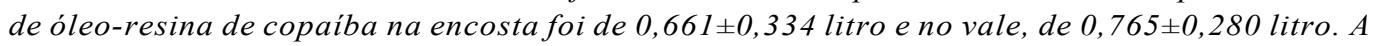




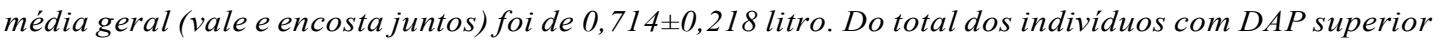
a $30 \mathrm{~cm}, 38$ individuos (58\%) produziram alguma quantidade de óleo-resina, com médias de 1,113 \pm 0,562 litro na encosta, 1,329 $\pm 0,448$ litro no vale e 1,190 $\pm 0,355$ litro nos dois ambientes. Os resultados encontrados apontam a necessidade de planejar também o uso de áreas vizinhas à área de estudo para que seja alcançado o volume necessário de copaíba que viabilize o manejo sustentável da atividade de extração de óleo-resina na região.

Palavras-chave: Biometria; Óleo-resina de copaíba; População natural.

\section{INTRODUCTION}

The trees of the Copaifera genus belong to the Fabaceae family and Caesalpinoideae subfamily. They are native to Latin America, from Mexico to northern Argentina and also in West Africa (HECK, 2012). Copaiba trees grow slowly and reach a height of 25-40 meters and can live up to 400 years. Their trunk is rough, dark in color and measures from 0.4 to 4 meters in diameter. Their fruit contains a ovoid seed surrounded by an aril. Flowering occurs between October and July and fruiting from June to October, with variations within these ranges depending on the region and climate, with no annual flourishing in some regions (VEIGA JR.; PINTO, 2002). In the region of Manaus, Amazonas, the flowering occurs from January to April and fruiting from March to August (BARBOSA et al., 2002).

The Copaifera genus has 72 species, including 16 found only in Brazil (VEIGA JR.; PINTO, 2002). Barbosa and Scudeller (2009) report that seven species of Copaifera L. can be found in the Amazon, what reveals a diversity of habitats, including several types of biomes in upland forests, wetlands, shores of lakes and streams in the Amazon basin and in savannah forests of Central Brazil and Roraima.

Copaiba oil is extracted from these trees. Its correct designation is oleoresin, as it is an exudate consisting of resin acids and volatile compounds. It is found in secretory channels located in all parts of the tree (VEIGA JR.; PINTO, 2002). Medeiros and Vieira (2008) report that these channels are formed by the dilation of intercellular spaces (meatus) that intercommunicate in the meristem, called schizogenous channels. The authors also point out that the most striking character of the secretory apparatus is in the trunk, where the longitudinal channels distributed in concentric tracks in the growth layers demarcated by the terminal parenchyma meet with an irregular lineation in woody

Revista Árvore, Viçosa-MG, v.40, n.1, p.51-60, 2016 layers, often without communicating. The oleoresin that builds up in cavities forming bags inside the tree trunk is a transparent and consistent liquid. Its color ranges from translucent yellow to dark brown. It has aromatic odor and is insoluble in water and partially soluble in alcohol (MEDEIROS; VIEIRA, 2008). According to Alencar (1982), oleoresin is the product of detoxification of the plant organism and acts as the plant's defense against animals and fungi.

Although there are several studies on this genus, little is known about its ecology and the factors that influence its greater or lesser production of oleoresin. The average oleoresin yield is 0.3 to 3 liters per tree at each collection (RIGAMONTE-AZEVEDO, 2006). According to the author, there is no safe indication that the exhaust of oleoresin during collection does not cause physiological damage or harm the tree's viability. The time required for the trees to accumulate oleo resin for successive extractions still requires further study to be indicated. Leite et al. (2001) state that the minimum rest period for the tree between extractions must be at least three years. However, Plowden (2003) advocates a range of six months to two years for each extraction, depending on each tree.

The use of copaiba oleores in by Indians in Brazil, which extends to traditional communities, has always been widespread, possibly from observing the behavior of certain animals that scratched themselves agains ttrunks of copaiba trees when wounded. The therapeutic use of copaiba oilis known since the seventeenth century and already appearedin the British Pharmaco poeia in 1677 and in the American one since 1820 (HECK, 2012).

Due to the importance of this resource for extractivist residents inside the Saracá-Taquera forest, we aimed in this work to study the populations of copaiba (Copaifera multijuga Hayne) in the hillsides and valleys 
of the Monte Branco mountain in Porto Trombetas, PA, which had been exploited for bauxite, to support the sustainable management and utilization of copaiba oleo resin by conducting $100 \%$ forest inventories, describing population structure and evaluating oleo resin yield.

\section{MATERIALAND METHODS}

\subsection{Description of the study area}

The Saracá-Taquera forest is located in the State of Pará on the right bank of Trombetas river in the cities of Oriximiná, Faro and Terra Santa. Its geographical coordinates are $1^{\circ} 20^{\prime}$ and $1^{\circ} 55^{\prime}$ South latitude and $56^{\circ} 00$ and $57^{\circ} 15^{\prime}$ West longitude. It borders north with the Biological Reserve of Trombetas River and southsouthwest with Nhamundá river (IBAMA, 2001).

Local climate is considered Equatorial Hot Humid and classified by Köppenas $A w$, with wet summer and dry winter. The driestmonths are August, September and October. The rainy season starts in December and ends in June. February, March and April are the three rainiest months. Average annual rainfall is around 2,000 $\mathrm{mm}$. Average air humidity is higher than $80 \%$. Average annual temperature ranges from 25 to $26{ }^{\circ} \mathrm{C}$ and the minimum, average and maximum daily temperature scan oscillate between 25 and $40{ }^{\circ} \mathrm{C}$ (IBAMA, 2001).

\subsection{Data collection}

We conducted a forest census on $100 \%$ of the copaiba trees (Copaifera multijuga Hayne) along the hillsides and valleys in the south face of Monte Branco mountain. For field activities we used a GPS device to guide the opening and record tracks as well as to obtain the coordinates of the copaiba trees. The initial and final limits of each track in the hillsides and valleys were defined according to the topography of the area, since the study site is located between two mountains: Monte Branco and Saracá. The inventory tracks in each environment (hillsides and valleys) were opened in parallel at a distance of 50 meters from each other. The plots of copaiba trees for data collection consisted of areas measuring 25 meters long by 50 meters wide.

The copaiba trees in the hillsides and valley were divided into natural regeneration and adult classes. The natural regeneration class consisted of the categories of newly sprouted plants, seedlings, rods, sticks and young plants, according to Jardim (1985) and Lima-
Filho et al. (2002), with modifications. We considered new ly sprouted plants as individuals with height up to $30 \mathrm{~cm}$. As for the other categories, we used the following criteria: seedling $(30 \mathrm{~cm}<$ height $<150 \mathrm{~cm})$; $\operatorname{rod}(150$ $\mathrm{cm}<$ height $<300 \mathrm{~cm}$ ); stick (height $>300 \mathrm{~cm}$ and $\mathrm{DBH} \leq$ $5 \mathrm{~cm})$; and young plants $(5 \mathrm{~cm}<\mathrm{DBH}<10 \mathrm{~cm})$. The adult class includes individuals with $\mathrm{DBH} \geq 10 \mathrm{~cm}$ and was divided into intervals of $10 \mathrm{~cm}$ each.

We counted the number of newly sprouted plants and recorded the number of occurrences in each inventory plot. We measured the total height and diameter at ground level of seedlings and rods. As for the sticks and young plants, we measured total height using a HAGA ${ }^{\circledR}$ hypsometer and circumference at breast height $(\mathrm{CBH})$ using a measuring tape, and then we calculated the DHB.

In what concerns to adult copaiba trees $(\mathrm{DBH}$ $\geq 10 \mathrm{~cm}$ ), we measured total height and trunk height at a distance of 20 meters from the tree. The height of the trunk was established as the distance between the ground and the first bifurcation of the branches, and the total height as the distance from the ground to the highest point of the crown following the vertical trunk axis. Canopy height was calculated by the difference between the total height and the height of the trunk. The $\mathrm{CBH}$ was measured with a tape at $1.3 \mathrm{~m}$ above ground level and the DBH was then calculated. The average crown diameter was calculated from the values of the larger and smaller diameters, measured with a tape at the projection of the crown.

We drilled all copaiba trees with $\mathrm{DBH} \geq 30 \mathrm{~cm}$, collected the oleo resin by the traditional local method and quantified the volume per tree using a beaker. Each copaiba tree was drilled with a 1 " auger at the height of $1 \mathrm{~m}$ from ground level and the oleoresin leaked until the flow stopped. After the extraction, the hole was sealed with a wood lathe and cut close to the trunk.

\subsection{Data analysis}

The total number of individuals was calculated per hectare (ind.ha ${ }^{-1}$ ) and separated into the categories of natural regeneration and adult classes. The adults were also separated into diameter classes in each environment.

We calculated the establishment efficiency rates of the number of individuals in all categories of the natural regeneration class and in the diameter class

Revista Árvore, Viçosa-MG, v.40, n.1, p.51-60, 2016 
of the adults to show the variation of the number of individuals in the category or class evaluated and the number of individuals in the subsequent category or diameter class. The calculation was made by the number of individuals in the subsequent category or diameter class divided by the number of individuals in the category or diameter class in question. Results are presented in percentage, in accordance with Rigamonte-Azevedo (2004).

As for the adult trees, we also calculated the average values of total height, trunk height, diameter at breast height, crown diameter and crown height. We compared the mean values of all biometric variables between both environments and between the diameter classes in 10$\mathrm{cm}$ intervals using Minitab ${ }^{\circledR} 16$ software.

We calculated the spatial distribution pattern as the ratio Variance/Mean(R): $\mathbf{R}=\mathbf{S}^{2} / \mathbf{x}$ (NASCIMENTO et al., 2001). Where $S^{2}=$ variance of frequency; $x=$ average value of frequency. When $\mathrm{R}<1$, the distribution pattern was considered non-clustered; when $\mathrm{R} \geq 1$ and $\mathrm{R} \leq 1.5$ it was considered as tendency to cluster and when $\mathrm{R}>1.5$ the distribution pattern was considered clustered.

We measured the distances between the points of occurrence of individuals and plotted on the map for each environment (valley and hillside) on the software ArcGis ${ }^{\circledR} 10$. Then we calculated the average distances and frequencies of distances into classes by the Sturges' formula, where $K=1+3.322 * \log 10(n) . K$ is the number of classes to be discovered and $n$ is the amount of sample data. We determined the amplitude of each of these classes by using the formula $\boldsymbol{H}=\boldsymbol{A T} / \boldsymbol{K}$, where $\mathrm{H}$ is the amplitude to be discovered, AT is the result of the maximum variance subtracted by the minimum variance of the sample and $\mathrm{K}$ is the number of classes set (HOEL, 1977).

We analyzed the results of copaiba oleoresin production in copaiba individuals with $\mathrm{DBH} \geq 30 \mathrm{~cm}$, and in diameter classes with amplitude of ten centimeters, between both environments (valley and hillside) and between dry and rainy periods of the year by analysis of variance (Minitab $\left.{ }^{\circledR} 16\right)$.

\section{RESULTS}

The total inventoried area was 234.51 hectares with 1,876 plots and density of 38.15 copaiba trees per hectare (ind.ha ${ }^{-1}$ ). The total area of the hillside was

Revista Árvore, Viçosa-MG, v.40, n.1, p.51-60, 2016
99.88 hectares with 799 plots and density of 41.16 ind.ha $^{-1}$. The total area of the valley was 134.63 hectares with 1,077 plots and density of 35.91 ind.ha ${ }^{-1}$.

There were 8,390 newly sprouted copaiba plants (3,842 in the hillside and 4,548 in the valley), with $4.5 \%$ establishment efficiency rate for both environments. Analysis of variance showed that the average number of newly sprouted plants was $70.2 \pm 26.3$ in the hillside and $101.9 \pm 32.7$ in the valley $(\mathrm{P}=0.454)$. The density in the hillside was 38.5 ind. $\mathrm{ha}^{-1}$ and 33.8 ind.ha $\mathrm{h}^{-1}$ in the valley. The total density of newly sprouted plants was 35.8 ind.ha $^{-1}$.

In the natural regeneration class there were 375 seedlings (190 in the hillside and 185 in the valley). The density in the hillside was 1.90 ind. $\mathrm{ha}^{-1}$ and the establishment efficiency rate was $6 \%$. In the valley, the density was 1.37 ind $\mathrm{ha}^{-1}$ and the establishment efficiency rate was $12 \%$. Total density was 1.6 ind.ha $^{-1}$.

There were 34 individuals in the rod category ( 12 in the hillside and 22 in the valley). The density of individuals in the hillside was 0.12 ind $\mathrm{ha}^{-1}$ and the establishment efficiency rate was $67 \%$. In the valley, the density was 0.16 ind $\mathrm{ha}^{-1}$ and the establishment efficiency rate was $27 \%$. Total density was 0.14 ind.ha $^{-1}$.

In the stick category there were 14 individuals ( 8 in the hillside and 6 in the valley). The density in the hillside was 0.08 ind ha $^{-1}$ and the establishment efficiency rate was $50 \%$. In the valley the density was 0.04 ind. $^{-1}$ and the establishment efficiency rate was $233 \%$. Total density in both environments was 0.06 ind.ha ${ }^{-1}$.

There were 18 young copaiba plants ( 4 in the hillside and 14 in the valley). Density was 0.04 ind.ha-1 in the hillside and 0.1 ind.ha $\mathrm{a}^{-1}$ in the valley. The establishment efficiency rates were $225 \%$ in the hillside and $114 \%$ in the valley. Total density in both environments was 0.08 ind $\mathrm{ha}^{-1}$.

There were 115 adult copaiba trees (DAP $\geq 10 \mathrm{~cm}$ ), of which 55 occurred in the hillside and 60 in the valley. The density of adult trees in the hillside was 0.55 ind.ha $^{-1}$ and 0.45 ind $\mathrm{ha}^{-1}$ in the valley. Total density in both environments was 0.49 ind.ha ${ }^{-1}$.

Figure 1 shows the establishment efficiency rates for the natural regeneration and adult classes in both environments. These results indicate that the more mature copaiba individuals are the slower they grow, 
what influences the accumulation of individuals on larger diameter classes up to a certain point. Posteriorly, the establishment efficiency rate lowers due to the probable increase in competition and mortality.

The density of copaiba individuals with $\mathrm{DBH} \geq$ $30 \mathrm{~cm}$ in the hillside was 0.33 ind.ha- $^{1}$, in the valley was 0.25 ind.ha- ${ }^{1}$, and in both environments together, the density was 0.28 ind.ha- ${ }^{-1}$. The largest tree diameter found in the valley was $61.43 \mathrm{~cm}$ and in the hillside was $68.12 \mathrm{~cm}$.

The average total height of adult copaiba trees in the valley and hillside increased together with the increase of the average diameter up to the 40-49.9 $\mathrm{cm}$ diameter class. The highest total height value of adult copaiba trees in the valley was $40 \mathrm{~m}$ and in the hillside was $42.5 \mathrm{~m}$. The average trunk height was higher in the valley, for the 20-29.9 cm and 50-59.9 $\mathrm{cm}$ diameter classes. Data show that the total height was influenced by the trunk height in all diameter classes in both environments (Figure 2). The largest trunk height value in the hillside was $25.9 \mathrm{~m}$ and in the valley was $25.0 \mathrm{~m}$.

The crown height of copaiba trees increased up to the $40-49.9 \mathrm{~cm}$ diameter class in the hillside as well as in the valley. In larger classes, there was a trend of crown height stabilization for trees in the hillside and crown height decrease for trees in the valley. The largest crown height value in the hillside was $22 \mathrm{~m}$ and in the valley was $23 \mathrm{~m}$. The average crown diameter of copaiba trees in the hillside increased with the increase of the DBH up to the 60-69.9 cm class, whereas in the valley the increase occurred up to the $50-59.9 \mathrm{~cm}$ class. The highest crown diameter in the hillside was 21.6 $\mathrm{m}$ and in the valley $21.56 \mathrm{~m}$.

There were no significant differences between the biometric measurements of adult trees in the hillside and valley (Table 1). The results showed no significant differences in $\mathrm{DBH}(\mathrm{P}=0.597)$, total height $(\mathrm{P}=0.432)$, trunk height $(\mathrm{P}=0.184)$, crown height $(\mathrm{P}=0.532)$ and crown diameter $(\mathrm{P}=0.484)$. There were no differences on the distribution pattern of the trees among the diameter classes and on the different environments of occurrence. Such results indicate that the individuals in both environments are part of the same population.

Table 2 shows the index that characterizes the spatial distribution pattern of copaiba trees in the natural regeneration and adult classes in the valley and hillside. In the hillside, the shortest distance between adults was $4.7 \mathrm{~m}$ and the highest was $3,607 \mathrm{~m}$, with an average of $1,327 \pm 17 \mathrm{~m}$. We found $29.5 \%$ of the adults up to $584 \mathrm{~m}$ distance among individuals, $39.4 \%$ of the adults up to $874 \mathrm{~m}$ distance, and $67 \%$ of the adults up to $1,744 \mathrm{~m}$ distance .In the valley, the shortest distance between adults was $2.5 \mathrm{~m}$, and the highest was $2,222 \mathrm{~m}$, with average of $844 \pm 9 \mathrm{~m}$. We found $33 \%$ of the adults up to $527 \mathrm{~m}$ distance among individuals, $56 \%$ up to $877 \mathrm{~m}$ distance, and $91 \%$ up to $1,752 \mathrm{~m}$ distance.

The total volume of copaiba oleoresin collected in the valley was 25.25 liters and in the hillside was 21.15 liters. In both environments, there was the same number of individuals (66) with $\mathrm{DBH} \geq 30 \mathrm{~cm}$. The average oleoresin yield collected in the hillside was $0.661 \pm$ 0.334 liters, and in the valley $0.765 \pm 0.280$ liters, with no significant difference $(P=0.370)$ between environments. The average value in both environments was $0.714 \pm 0.218$ liters, with a maximum of 10.1 liters from a single individual in the hillside and 8 liters from a single individual in the valley.

The copaiba trees in larger diameter classes yielded larger quantities of oleoresin with fewer individuals (Table 3 ). The inventory was $100 \%$ and the variation in the oleoresin collected among individuals is not only related to the size of the individual, but also to other factors, probably in the formation of internal structures of the trees for oleo resin buildup.

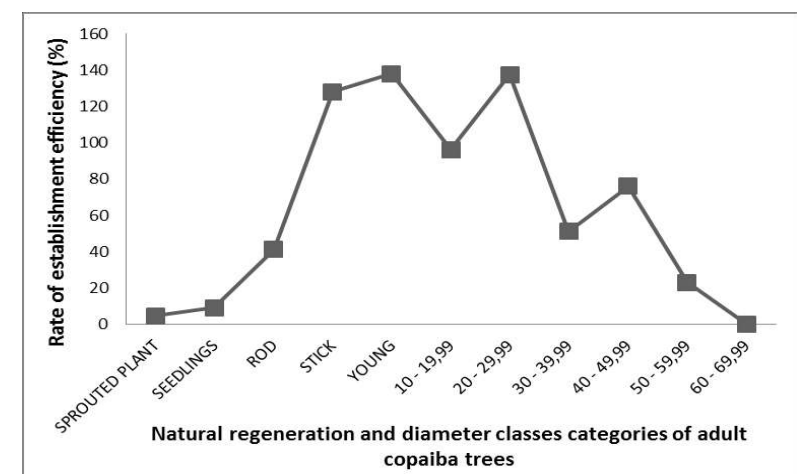

Figure 1 - Rate of establishment efficiency in the natural regeneration and diameter classes categories of adult copaiba trees.

Figura 1-Taxa de eficiência de estabelecimento nas categorias de regeneração natural e classes de diâmetro de copaibeiras adultas.

Revista Árvore, Viçosa-MG, v.40, n.1, p.51-60, 2016 

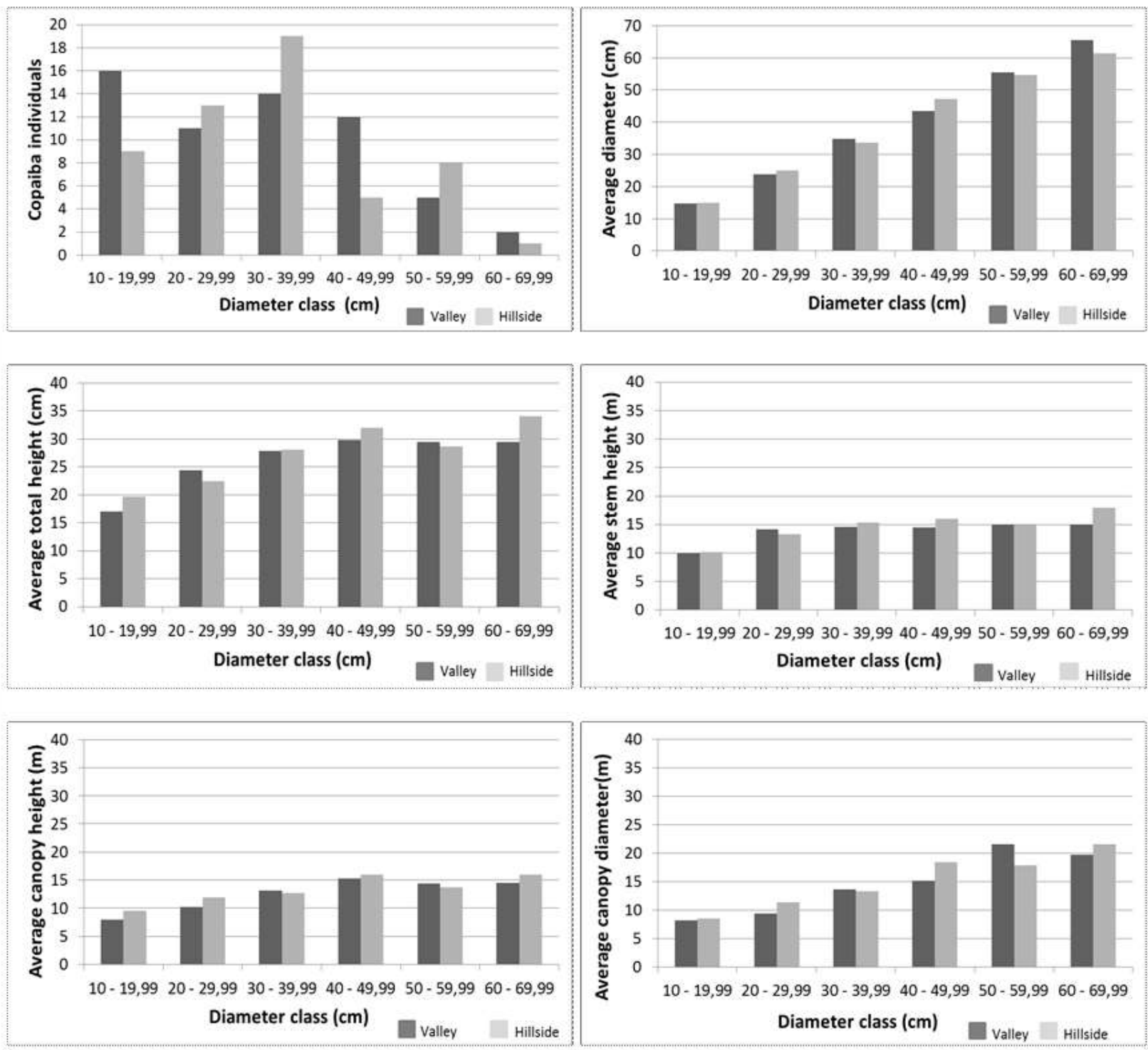

Figure 2 - Frequencies of copaiba individuals; Average diameter of copaiba; Average total height of copaiba; Average stem height of copaiba; Average canopy height of copaiba and average canopy diameter of copaiba by diameter class in the valley and hillside.

Figura 2 -Frequências de indivíduos de copaíba; Diâmetro médio de copaíba; Altura total média de copaíba; Altura de tronco média de copaíba; Altura de copa média de copaíba; e Diâmetro de copa médio de copaíba por classe diamétrica no vale e encosta.

In $38(58 \%)$ of the individuals with $\mathrm{DBH} \geq 30 \mathrm{~cm}$, some amount of oleoresin was collected. This percentage of productive individuals reveals the potential for oleoresin extraction in the area; we found oleoresin yield averages of $1.113 \pm 0.562$ liters in the hillside, $1.329 \pm 0.448$ liters in the valley, and $1.190 \pm 0.355$ liters

Revista Árvore, Viçosa-MG, v.40, n.1, p.51-60, 2016 in both environments together. The average volume difference of oleoresin collected between hillside and valley was significant $(\mathrm{P}=0.041)$.

The average volume of oleoresin collected between extraction seasons (dry season and rainy season) had 
Table 1 - Biometric average values and standard error of adult individuals of copaiba with $\mathrm{DBH} \geq 10 \mathrm{~cm}, \mathrm{DBH} \geq 30 \mathrm{~cm}$ and productive individuals in valleys and hillsides of the south face of Monte Branco, Mineração Rio do Norte Porto Trombetas-PA.

Tabela 1 - Valores biométricos médios e erro-padrão dos indivíduos adultos de copaíba com DAP $\geq 10 \mathrm{~cm}, D A P \geq 30 \mathrm{~cm}$ e indivíduos produtivos nos vales e encostas da face Sul do Monte Branco, Mineração Rio do Norte Porto Trombetas-PA.

\begin{tabular}{lcccccc}
\hline Individuals & $\mathrm{H}(\mathrm{m})$ & $\mathrm{TH}(\mathrm{m})$ & $\mathrm{CH}(\mathrm{m})$ & $\mathrm{CD}(\mathrm{m})$ & $\mathrm{DBH}(\mathrm{cm})$ & Environment \\
\hline $\mathrm{DBH} \geq 10 \mathrm{~cm}$ & $28.4 \pm 0.8$ & $14.0 \pm 0.6$ & $12.4 \pm 0.7$ & $13.5 \pm 0.6$ & $33.3 \pm 1.8$ & HILLSIDE \\
$\mathrm{DBH} \geq 10 \mathrm{~cm}$ & $24.9 \pm 0.8$ & $12.9 \pm 0.6$ & $11.9 \pm 0.6$ & $12.6 \pm 0.7$ & $31.9 \pm 1.9$ & VALLEY \\
$\mathrm{DBH} \geq 10 \mathrm{~cm}$ & $25.6 \pm 0.6$ & $13.5 \pm 0.4$ & $12.2 \pm 0.5$ & $12.9 \pm 1.1$ & $32.6 \pm 1.3$ & GENERAL \\
$\mathrm{DBH} \geq 30 \mathrm{~cm}$ & $28.9 \pm 0.9$ & $15.4 \pm 0.8$ & $13.6 \pm 0.9$ & $15.6 \pm 0.7$ & $41.6 \pm 1.8$ & HILLSIDE \\
$\mathrm{DBH} \geq 30 \mathrm{~cm}$ & $28.8 \pm 0.7$ & $14.5 \pm 0.7$ & $14.5 \pm 0.5$ & $15.9 \pm 0.8$ & $42.9 \pm 1.7$ & VALLEY \\
$\mathrm{DBH} \geq 30 \mathrm{~cm}$ & $28.9 \pm 0.6$ & $14.9 \pm 0.5$ & $14.0 \pm 0.5$ & $15.7 \pm 1.9$ & $42.3 \pm 1.2$ & GENERAL \\
$\mathrm{PRODUCTIVE}$ & $30.1 \pm 1.0$ & $16.0 \pm 1.2$ & $14.1 \pm 1.2$ & $16.8 \pm 0.5$ & $45.2 \pm 2.4$ & HILLSIDE \\
PRODUCTIVE & $27.8 \pm 0.9$ & $14.5 \pm 0.7$ & $13.4 \pm 0.6$ & $16.3 \pm 1.2$ & $43.1 \pm 2.0$ & VALLEY \\
PRODUCTIVE & $28.8 \pm 0.7$ & $15.2 \pm 0.7$ & $13.6 \pm 0.7$ & $16.3 \pm 2.3$ & $43.8 \pm 1.5$ & GENERAL \\
\hline
\end{tabular}

$\mathrm{H}=$ total heigh; $\mathrm{TH}=$ trunk heigh; $\mathrm{CH}=$ canopy heigh; $\mathrm{CD}=$ canopy diameter; e $\mathrm{DBH}=$ diameter at breast height.

$H=$ altura total; $H t=$ altura de tronco; $H c=$ altura de copa; $D c=$ diâmetro de copa; and DAP = diâmetro à altura do peito.

Table 2 - Variance/mean ratio (R Index) for copaiba regarding the natural regeneration categories and adult individuals in the valleys and hillsides of the south face of Monte Branco, Mineração Rio do Norte Porto Trombetas-PA.

Tabela 2 - Razão variância/média (Índice R) para copaíba em relação às categorias de regeneração natural e indivíduos adultos no vale e encosta da face Sul do Monte Branco, Mineração Rio do Norte Porto Trombetas-PA.

\begin{tabular}{lcccc}
\hline Environment & Seedling & Rod & Stick & Young \\
Hillside & Clustered & Clustered & Non clustered & Non clustered \\
Valley & Clustered & Tendency to cluster & Tendency to cluster & Tendency to cluster \\
\hline
\end{tabular}

Table 3 - Average volume and standard error of copaiba oleoresin with DBH $\geq 30 \mathrm{~cm}$ and productive individuals in valleys and hillsidess of the south face of Monte Branco, Mineração Rio do Norte Porto Trombetas-PA.

Tabela 3 - Volume médio e erro-padrão de óleo-resina de copaíba com DAP $\geq 30 \mathrm{~cm}$ e indivíduos produtivos nos vales e encostas da face Sul do Monte Branco, Mineração Rio do Norte Porto Trombetas-PA.

\begin{tabular}{lccccc}
\hline Average Volume & $\mathbf{3 0 - 3 9 . 9 9}$ & $\mathbf{4 0 - 4 9 . 9 9}$ & $\mathbf{5 0 - 5 9 . 9 9}$ & $\mathbf{6 0 - 6 9 . 9 9}$ & Environment \\
\hline $\mathrm{DBH} \geq 30 \mathrm{~cm}$ & $0.049 \pm 0.027$ & $0.400 \pm 0.292$ & $1.015 \pm 0.573$ & $10.100 \pm 0.0$ & HILLSIDE \\
$\mathrm{DBH} \geq 30 \mathrm{~cm}$ & $0.229 \pm 0.075$ & $0.621 \pm 0.201$ & $1.920 \pm 1.537$ & $2.500 \pm 2.500$ & VALLEY \\
$\mathrm{DBH} \geq 30 \mathrm{~cm}$ & $0.125 \pm 0.038$ & $0.556 \pm 0.163$ & $1.363 \pm 0.661$ & $5.033 \pm 2.916$ & GENERAL \\
PRODUCTIVE & $0.103 \pm 0.051$ & $1.000 \pm 0.500$ & $1.160 \pm 0.640$ & $10.100 \pm 0.0$ & HILLSIDE \\
PRODUCTIVE & $0.400 \pm 0.093$ & $1.064 \pm 0.219$ & $3.200 \pm 2.413$ & $5.000 \pm 0.0$ & VALLEY \\
PRODUCTIVE & $0.243 \pm 0.062$ & $1.050 \pm 0.187$ & $1.772 \pm 0.822$ & $7.550 \pm 2.550$ & GENERAL \\
\hline
\end{tabular}

no significant difference $(\mathrm{P}=0.682)$. The average yield during the rainy season was $0.508 \pm 0.229$ liters and during the dry season was $0.807 \pm 0.310$ liters. The percentage of productive individuals was $57 \%$ during the rainy season and 58\% during the dry season. Other factors may influence copaiba oleoresin yield in the first extraction as each tree has its own physical characteristics and environmental interactions.

\section{DISCUSSION}

Individuals of the newly sprouted plants, seedlings and rods categories showed low rates of establishment efficiency, possibly because they suffer greater predation, and also, as a result of increased competition for nutrients and light when located under the mother tree. Lima Filho et al. (2002) found that only 5\% of natural regeneration individuals, including copaiba, could reach the canopy.

The results of this study indicate that $1.3 \%$ of the newly sprouted plants and $30 \%$ of the seedlings of copaiba trees become adults $(\mathrm{DBH} \geq 10 \mathrm{~cm})$. According to the extractive workers who participated in this study, most of the predation of the newly sprouted plants occurs by animals, such as deer (Cervus elaphus) that 
graze on the seedling banks, and rodents (Dasyprocta leporina and Cuniculus paca) that dig up the seeds in search for food. Other animals such as tapirs (Tapirus terrestres) and wild pigs (Tayassu tajacu and Tayassu peccary) visit the copaiba trees to grease up their bodies with oleoresin that leaks down the trunk and to feed off the sprouts as a complementary treatment.

The highest regeneration efficiency rate shows that, even with high mortality in the smaller classes, individuals of the stick and the young categories tend to settle. Most individuals found in these categories were far from the mother tree, and for having larger size escaped predation. Environmental factors such as availability of light and nutrients related to their location also influence the establishment. High regeneration efficiency rates can also be an indicator that the more mature copaiba individuals are, the slower they grow, what influences accumulation in these categories.

Barbosa and Scudeller (2009) found density of 1.7 ind.ha- ${ }^{1}$ in an area of 13 hectares. Chambers et al. (2009) also considering individuals with $\mathrm{DBH} \geq 10 \mathrm{~cm}$, found density of 0.8 ind.ha- ${ }^{1}$ in 5 hectares. Plowden (2003), in Pará State, also considering individuals with $\mathrm{DBH} \geq 10 \mathrm{~cm}$, found density of 0.86 ind.ha- ${ }^{1}$ in 7 hectares. Rigamonte-Azevedo (2006) found density of 0.74 ind.ha- $^{1}$ in 37 hectares in Acre State. Alencar (1982) found density of 0.41 ind.ha- ${ }^{1}$ in 200 hectares in the Adolpho Ducke Reserve near the city of Manaus, Amazonas.

The density results of the present study $\left(0.55\right.$ ind.ha- ${ }^{1}$ in the hillside and 0.45 ind. $^{-{ }^{1}}{ }^{1}$ in the valley - with an average value of 0.49 ind.ha- $^{1}$ in 234.51 hectares) are similar to those found by Alencar (1982) as well as the area of study and the ecological specificities of each of the locations studied.

The higher trend in DBH increase of the copaiba trees in the valley, in the three largest diameter classes, shows that the trees reached the forest canopy, growing larger in diameter than proportionally in height, whereas in the hillside, the lower trend in DBH increase in these three classes, shows that the trees are still investing more in height than in diameter. Such data reinforce the evidence that the trees reached the forest canopy from the 40-49.9 cm diameter class on.

Alencar (1984) found clustered distribution pattern of natural regeneration individuals and random distribution pattern of adults studied in the Amazonas

Revista Árvore, Viçosa-MG, v.40, n.1, p.51-60, 2016
State. Barbosa and Scudeller (2009) also cite the random distribution pattern of adults in the Amazonas State. Newton et al. (2011) found clustered pattern of adult copaiba trees in the Amazon, what corroborates with the result found in this work, with a tendency to cluster pattern or a clustered pattern.

The clustered pattern or with a tendency to cluster is in agreement with the traditional knowledge of extractivists who often say that copaiba trees (copaibeiras) occur in "reboleiras", that is, some places concentrate some trees of the species scattered along stream banks and also in some dry land parts. This fact facilitates the exploration planning of the area as it enables the establishment of extraction routes and oleoresin production units, taking into account the distances to be traveled, the necessary labor time and the productive capacity of the area.

The highest amounts of oleoresin collected were from the larger diameter classes. However, it is not possible to say that the production is related only to this variable although the known local tradition recommends to practice the extraction of oleoresin in individuals with diameters greater than $45 \mathrm{~cm}$, which confirms the study of Medeiros and Vieira (2008) that links individuals with $\mathrm{DBH} \geq 40 \mathrm{~cm}$ as the largest producers in a first collection. Plowden (2003) states that the trees with $\mathrm{DBH} \geq 65 \mathrm{~cm}$ are in advanced age and have a large proportion of hollowed individuals.

A larger average volume of oleoresin was collected from copaiba trees of larger diameter classes (DBH $\geq 40 \mathrm{~cm}$ ), even with fewer individuals. This may serve as guide in which individuals with $\mathrm{DBH}<40 \mathrm{~cm}$ should not be exploited for a productive supply to ensure further exploitation of this resource.

Several studies (ALENCAR, 1982; PLOWDEN, 2003; MEDEIROS; VIEIRA, 2008) sought to measure how much time it takes for a copaiba tree to go back to accumulate oleoresin and when is it possible to perform successive extractions again. However, the great difficult in monitoring individuals that are exploited for the first time and in all subsequent explorations is the need for more replicates and longer follow-up in order to have greater precision in recommending a minimum time for this resource's reposition.

Some authors differentiate yield values separating the productive individuals from non-productive ones and quantifying the percentage of those productive. 
In the state of Acre, Rigamonte-Azevedo (2006) found $29.4 \%$ of productive copaiba trees in a population of 273 , and $40 \%$ in a population of 115 individuals, with an average yield of 2.92 liters per tree for both populations. In Amazonas State, Scudeller and Barbosa (2009) found $44 \%$ of productive individuals with a mean yield of 0.746 liters per tree. Medeiros and Vieira (2008) selected 43 individuals and found $62 \%$ productive ones that had not yet been drilled and collected 28.2 liters of oleo resin. Plowden (2003), in Pará State, found $61 \%$ of productive individuals, what approaches the result found in this study $(58 \%)$. These results can help in the production potential exploring planning of a population of copaiba trees in the Amazon Region.

\section{CONCLUSION}

Copaiba individuals of the natural regeneration and adult classes showed establishment efficiency rates that enabled the maintenance of a population in the study area. However, the slow growth of the species suggests the need for studies of the enrichment of the copaiba planting areas in order to evaluate the time that an individual takes to reach diameters suitable for oleoresin extraction.

The average volume of oleoresin of the study area, combined with the high demand of copaiba extractivists of the region, show that for the ecological and economic sustainability of the copaiba oleoresin extraction activity, it is necessary to use nearby areas to achieve the volume required.

Location studies of copaiba individuals and mapping of potentially productive areas, as well as the standardization of non-predatory extraction techniques are characterized as fundamental actions for the ecologically sustainable use. Planning for the extraction of copaiba oleoresin, respecting the minimum cycle of replacement of this resource and the establishment of annual production units and extraction routes can ensure greater effectiveness to this extractive activity.

\section{REFERENCES}

ALENCAR, J.D.C. Estudos silviculturais de uma população natural de Copaifera multijuga Hayne - Leguminosae, na Amazônia Central. 2 Produção de óleo-resina. Acta Amazônica, v.12, n.1, p.75-90, 1982.

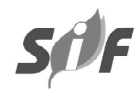

ALENCAR, J.D.C. Estudos silviculturais de uma população natural de Copaifera multijuga Hayne Leguminosae, na Amazônia Central. 3 -

Distribuição espacial da regeneração natural préexistente. Acta Amazônica, v. 14, n.1, p.255-279, 1984.

BARBOSA, A.P.; PINTO, A.M.; RIBEIRO, R.J. Calendário de floração e frutificação de espécies madeireiras da região Amazônica. Manaus: 2002. (Calendário de Fenologia).

BARBOSA, K.S.; SCUDELLER, V. Diversidade biológica: distribuição das espécies do gênero Copaifera L. na Amazônia Legal e aspectos morfológicos de C. multijuga Hayne da reserva de Desenvolvimento Sustentável do Tupe, ManausAm. In: SANTOS-SILVA, E.N.; SCUDELLER, V.V. Biotupé: meio físico, diversidade biológica e sociocultural do Baixo Rio Negro, Amazônia Central. Manaus: Uea Edições, 2009. p.135-142.

CHAMBERS, J. Q., DOS SANTOS, J., RIBEIRO, R.J., HIGUCHI, N. LBA-ECO CD-08 Tree Inventory Data, Ducke Reserve, Manaus, Brazil: 1999. Data set from Oak Ridge National Laboratory Distributed Active Archive Center, Oak Ridge: Tennessee, U.S.A., 2009. Disponível em: http://daac.ornl.gov. Acesso: 31 ago 2012.

INSTITUTO BRASILEIRO DO MEIO AMBIENTE E DOS RECURSOS NATURAIS RENOVÁVEIS IBAMA. Plano de Manejo da Floresta Nacional de Saracá-Taquera, Estado do Pará-Brasil. Curitiba: 2001.

HECK, M.C.; VIANA, L.A.;VICENTINI, V.E. Importância do óleo de Copaifera sp. SaBios: Revista Saúde e Biologia, v.7, n.1, p.82-90, 2012.

HOEL, P.G. Estatística elementar. São Paulo: Atlas, 1977. 430p.

JARDIM, F.C. Estrutura da floresta equatorial úmida da estação experimental de Silvicultura Tropical do INPA. 1985. 185f. Dissertação (Mestrado em Botânica Econômica) - INPA/FUA, Manaus, 1985.

LEITE, A.; ALECHANDRE, A.; RIGAMONTEAZEVEDO, O.C.; OLIVEIRA, A.

Revista Árvore, Viçosa-MG, v.40, n.1, p.51-60, 2016 
Recomendações para o manejo sustentável do óleo de copaíba. Série: Manejo sustentável de florestas tropicais. Rio Branco: UFAC/SEFE, 2001.

LIMA-FILHO, D.A.; REVILLA, J.; COELHO, L.S. Regeneração natural de três hectares de floresta ombrófila densa de terra firme na região do rio Urucu-Am, Brasil. Acta Amazônica, v.32, n.4, p.555-569, 2002.

MEDEIROS, R.S.; VIEIRA, G. Sustainability of extraction and production of copaiba (Copaifera multijuga Hayne) oleoresin in Manaus, AM, Brazil. Forest Ecology and Management, v.256, p.282-288, 2008.

NASCIMENTO, A.R.; LONGHI, S.J.; BRENA, D.A Estrutura e padrões de distribuição espacial de espécies arbóreas em uma amostra de floresta ombrófila mista em Nova Prata, RS. Ciência Florestal, v.11, n.1, p.105-119, 2001.

NEWTON, P.; WATKINSON, A. R.; PERES, C. A. Determinants of yield in a non-timber forest product: Copaifera oleoresin in Amazonian extractive reserves. Forest Ecology and Management, Amsterdam, v. 261, p. 255-264, 2011.

PLOWDEN, C. Production ecology of copaíba (Copaifera spp.) oleoresin in the Eastern Brazilian Amazon. Economic Botany, v.57, p.491-501, 2003.

RIGAMONTE-AZEVEDO, O.C. Copaíba: estrutura populacional, produção e qualidade do óleo-resina em populações nativas do sudoeste da Amazônia. 2004. 83f. Dissertação (Mestrado em Ecologia e Manejo de Recursos Naturais) - Universidade Federal do Acre, Rio Branco, 2004.

RIGAMONTE-AZEVEDO, O.C.; WADT, P.G.S.; WADT, L.H.O. Potencial de produção de óleoresina de copaíba (Copaifera $\mathrm{spp}$ ) de populações naturais do Sudoeste da Amazônia. Revista Árvore, v.30, n.4, p.583-591, 2006.

VEIGA JR, V.F.V.; PINTO, A.C. O Gênero Copaifera L. Química Nova, v.25, n.2, p.273-286, 2002. 